\title{
비첨성형술
}

울산 대학교 의과대학 서울아산병원 이비인후과학교실

장 용 주·이 시 형

\section{Surgery of the Nasal Tip}

Yong Ju Jang, MD and Si Hyung Lee, MD

Department of Otolaryngology, Asan Medical Center, University of Ulsan College of Medicine, Seoul, Korea

\section{서 론}

최근 과거에 비해 코성형에 있어 코끝 모양에 대한 관 심이 높아지고 있으며 코성형술의 성공을 좌우하는 마 무리 단계인 비첨성형술의 중요성이 점차 강조되고 있 다. 비첨의 모습은 주로 비익연골의 모양과 크기에 의해 결정되며 주위 연조직에 의해 그 모습이 유지되고 있으 므로 성공적인 비첨 성형을 위해서는 비익연골의 해부 학적 특징과 주위구조와의 역학관계에 대한 충분한 이 해가 필수적이다. 비첨 성형은 크게 비익연골의 부피 감 소(volume reduction)을 위한 절제(excision)와 윤곽 (definition)을 위한 절개(incision)의 조합이라고 할 수 있다. 성공적인 비첨성형술은 개개인의 안면 성상과 잘 어울리는 수술을 받지 않은 듯한 모습을 만드는 것으로 술전 정확한 진단과 충분한 분석 그리고 정교한 술기가 조화를 이룰 때 가능한 것이다. 본 논문에서는 비첨성형 술의 기초적인 면과 실제적인 면을 개괄하고자 한다.

\section{비첨성형술의 기본적 개념}

\section{비첨의 해부}

비첨을 경계 짓는 비첨 한정점(tip defining point;

교신저자 : 장용주, 138- 736 서울 송파구 풍납 2동 388- 1 울산대학교 의과대학 서울아산병원 이비인후과학교실 전화 : (02) 3010- 3712. 전송 :(02) 489- 2773 E- mail : jangyj@amc.seoul.kr
T DP) 은 상비첨점( supratip break), 좌우 비익연골의 천장부(dome), 하비첨점(infratip break, columellar breakpoint, columellar lobular junction) 의 4 가지 해부 학적 표지(landmark)에 의해 형성되고 정면에서 볼 때 마름모형을 이루게 된다. 코성형술시 비첨 한정점이 잘 나 타나도록 해야 자연스러운 형태를 얻을 수 있다(Fig. 1). 비익연골의 내측각(medial crura) 은 비첨을 지탱하는 지주로 비주(columella) 를 형성한다. 이는 치밀한 섬유 성 조직과 단단히 결합되어 있으며 피하지방조직이 없 는 피부로 덮혀 있다. 내측각의 족판(footplate)은 비중 격과 인대로 연결되어 있지 않으며 단지 비중격의 미부 를 둘러싸고 있다.비익연골의 중간각(middle crura, intermediate crura) 은 해부학적 변이가 가장 많은 부분 으로 소엽부(lobular segment)와 천장부(domal segment) 로 나눌 수 있다. 천장부(dome)는 비익연골의 가 장 돌출된 부분을 말하며 좌우 비익연골의 천장부는 비 첨의 모양을 결정하는 중요한 표지가 된다. 좌우 중간각 에 의해 형성되는 정상 분산각은 평균 $50 \sim 60^{\circ}$ 를 이룬 다. 비익연골의 외측각(lateral crura) 은 대부분의 비익 을 형성하며 두측연(cephalic border)에서 상외측비연 골과 접합부(scroll junction) 를 이루며 단단히 결합하 고 있다. 비익연골의 미측 경계(caudal margin)와 비공 연(alar rim)간의 거리는 위치에 따라 다르며 천장부에 서 $6 \mathrm{~mm}$, 외측각의 중앙부에서 $5 \mathrm{~mm}$, 외측각의 후방 부위에서 $13 \mathrm{~mm}$ 정도 떨어져 있어 경계절개(marginal incision)를 가할 경우 비공연이 아니라 비익연골의 미 
측 경계와 평행하게 시행하는 것이 중요하다. 비익연골 은 상외측비연골과는 달리 비중격의 지지를 받지 못하 고 몇가지 연조직에 의해 지탱되고 있으므로 이러한 해 부학적 특성을 이해하고 그 특성을 이용하여 비첨성형술 을 시행해야 한다. 비익연골 및 비첨의 지지기전은 주지 지구조와 부가적 지지구조로 설명할 수 있다 비익연골 의 모양과 강도, 내측 족판과 미측 비중격의 결합, 비익 연골과 상외측비연골의 결합이 주된 비첨의 지지구조이 며 비첨의 인대, 연골성 비배부, 비극(nasal spine), 등 이 부가적인 지지구조에 해당한다(Fig. 2, Table 1). 한 편 동양인의 코는 서양인과는 다른 특징을 가지고 있어 비첨 성형 시 더욱 주의를 요한다. 일반적으로 동양인의 코는 상대적으로 작고 완만한 굴곡을 가진 비익연골, 둥 글고(round) 살집이 많으며(fleshy) 피부가 두껍고 거 친 비첨부, 둥글게 벌어진(flared) 비공, 두껍고 넓게 벌

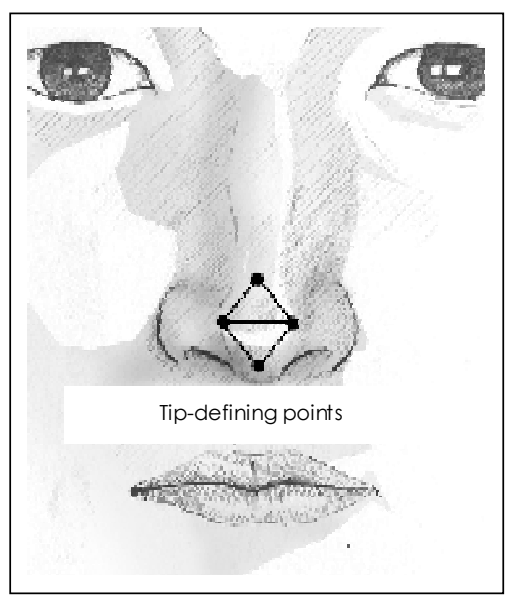

Fig. 1. Tip defining points. 어진(wide- based) 비소엽 등으로 특징지어 진다.

\section{비첨의 분석(Analysis)}

비첨 성형을 위해서는 비첨의 폭(width), 윤곽(definition), 부피(volume), 회전 정도(rotation), 위치(position), 융기정도(projection) 및 비익- 비주의 관계에 대 해 정확히 분석해야 하며 전면, 측면, 사면, 및 기저면에 서 다각적인 관찰이 필요하다. ${ }^{1)}$ 코를 전면에서 보았을 때 상비첨점과 하비첨점은 안면 중앙의 수직선상에 위 치해야 하며, 좌우 비익연골의 천장부는 비첨에서 같은 거리에 위치해야 한다. 코의 측면상에서는 비근점, 상비 첨점, 하비첨점, 비익 주름(alar crease) 등의 해부학적 표지를 바탕으로 비첨의 위치, 회전, 융기 정도 등을 분 석해야 하며 비익- 비주의 관계도 중요하다(Fig. 3). 이 상적인 모양의 비익연(alar margin) 은 완만한 S 형태를

Table 1. The support mechanism of nasal tip

Major tip support mechanism
The thickness, size, shape, and contour of alar cartilage
The connective tissue relationship between
the caudal margin of upper lateral cartilage and
the cephalic marin of alar cartilage
The medial crural footplate attachment to
the caudal quadrangular cartilage
Minor tip support mechanism
Nasal tip interdormal ligament
Cartilaginous dorsum
Nasal spine
Strength, length, and resilience of the medial and
intermediate crura
Thickness of tip skin-subcutaneous complex
Supportive strength of alar sidewalls

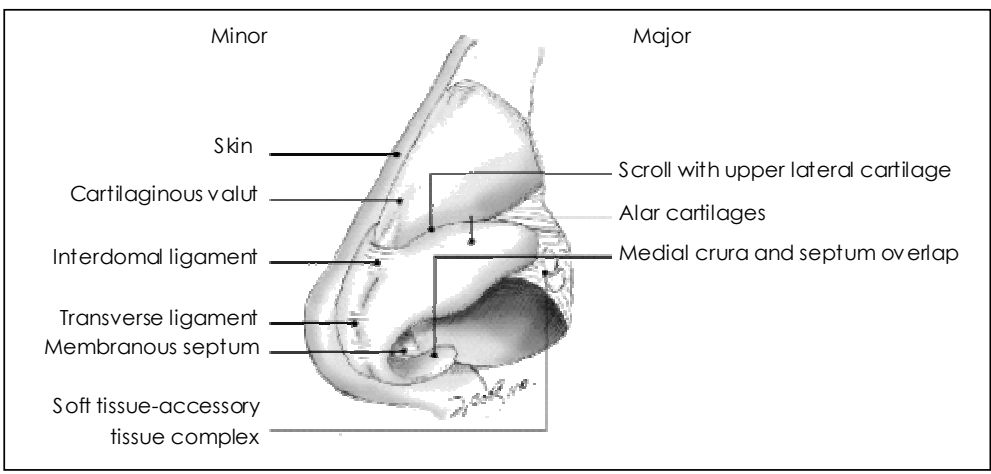

Fig. 2. Tip support mechanism. 


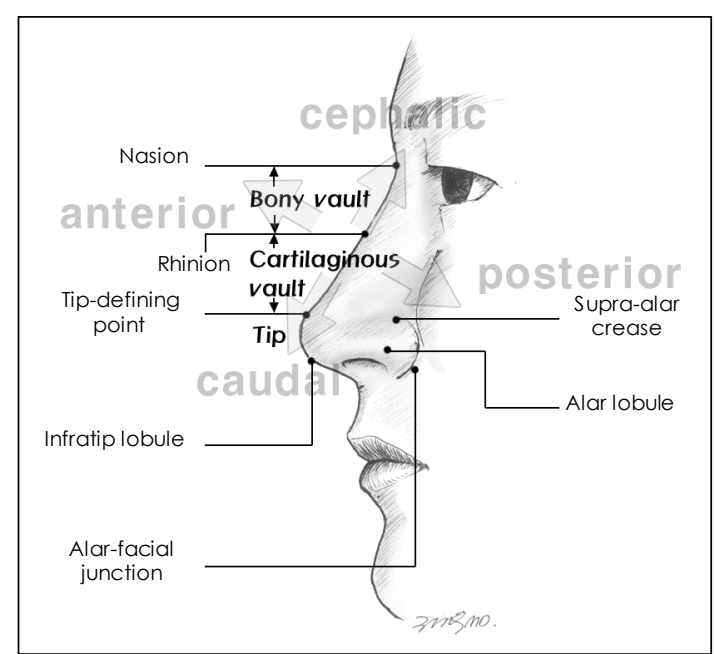

Fig. 3. Anatomical landmarks and orientation in the profile view.

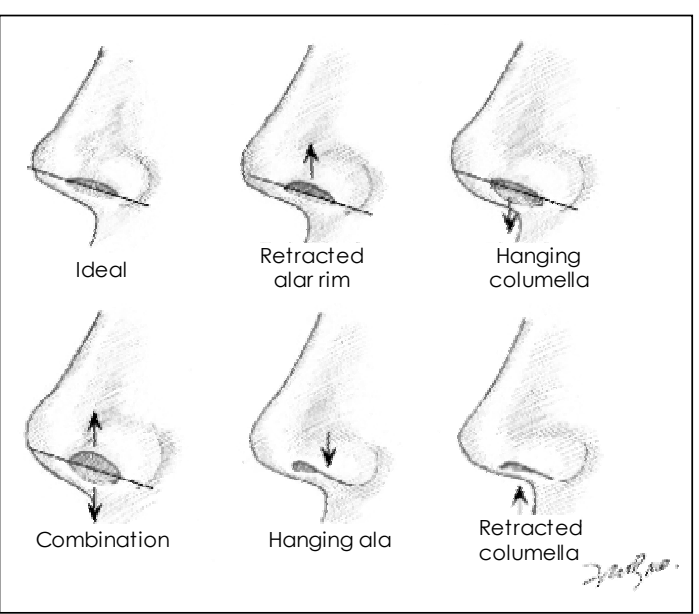

Fig. 4. Alar-columellar relationship.

보이면서 대체로 비주의 미측연에 평행하게 그려지며 측 면상에서 미측 비주가 2 4 mm 이상 노출되지 않는다. 만약 비익이 지나치게 높은 만곡(high arch)을 나타내 는 경우나(retracted alar rim), 또는 비익연골 중간각 과 내측각의 만곡(convexity)이 과도한 경우(hanging columella) 비주의 노출이 많아진다(Fig. 4). ${ }^{2)}$ 콧등과 이 마가 비근점에서 이루는 비전두각은 서양인에서는 115 $130^{\circ}$ 가 이상적이나 동양인은 미간이 낮아 $135 \sim 140^{\circ}$ 를 가장 선호하며 비순각은 $90 \sim 95^{\circ}$ 가 적당하다. 코의 사 면상에서 반대측의 천장부가 가장 높은 지점이 될 때 이상

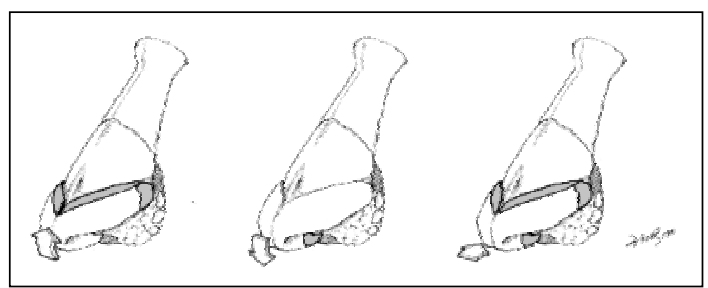

Fig. 5. Anderson's tripod concept.

적이며 기저면에서는 코의 삼각형 모양(triangularity), 비첨하 소엽(infratip lobule)과 비공의 비율, 및 비공의 모양 등을 관찰하는데 코는 이등변삼각형의 모양을 하 고 있고 비주와 소엽의 비율은 $2: 1$ 을 보이며 비공의 모양은 눈물방울(teardrop) 형태이다.

\section{기본 개념}

비첨 성형의 기본 원리는 삼각이론(tripod theory)으 로 설명할 수 있다. ${ }^{3)}$

이는 비익연골의 내측각과 외측각을 3 개의 다리로 보 고 어느 쪽 다리든지 하나를 자르면 길이가 짧아지므로 그 방향으로 회전이 일어난다는 것이다. 만약 하부 쪽 다 리를 절제하면 비첨 융기가 감소하고 아래 방향으로 회 전할 것이고, 외측각을 절제하면 비첨은 융기하고 상방 향으로 회전할 것이다(Fig. 5). 비첨융기와 비첨회전은 서로 상승작용을 한다. 만약 내측각을 받침이식(plumping graft)으로 연장시킬 경우 비첨은 위쪽을 향할 것이 며, 여기에 외측각의 절제를 더하면 비첨융기와 회전을 더욱 증가시킬 것이다. 비첨성형술에서는 한 가지 방법 을 단독으로 사용하기 보다는 여러 술식을 복합하여 원 하는 모양을 만들게 된다.

\section{비첨 성형의 술식}

\section{절개법(Incision)}

코성형을 위한 절개는 크게 비익연골절개(alar cartilage incisions), 비중격절개( septal incisions), 비주횡 절개(transcolumellar incisions) 로 나눌 수 있다. 비익 연골절개에는 연골간절개(intercartilaginous incision), 경연골절개( intracartilaginous, transcartilaginous incision), 경계절개( infracartilaginous, marginal incision) 
등이 있다(Fig. 6). 연골간절개는 상, 하외측비연골의 접 합부 즉, 비밸브 부근에 시행하게 된다. 이곳의 절개는 드물게 비밸브 협착(valvular stenosis)을 초래할 수 있 으므로 밸브에서 1 2 $\mathrm{mm}$ 정도 아래의 비익연골 외측 각 위에 절개선을 넣는 것이 좋다. ${ }^{4)}$ 연골간절개는 역행 성 접근법(retrograde approach)을 통한 외측각의 외반 (eversion)이나 경계절개와 동반하여 노출법(delivery approach)을 통해 비첨 교정에 이용할 수 있다. 경연골 절개는 비익연골의 외측각 미측연의 $4 \sim 6 \mathrm{~mm}$ 상방에서 갈매기 날개모양( gull wing) 으로 시행되며 연골절개접근 법(cartilage splitting approach)시 사용할 수 있다. 경 계절개는 비익연골의 아래쪽 경계를 따라 넣는다. 비익 연골의 하연에서 비익 끝까지의 거리는 연삼각( soft triangle) 부위에서 $2 \mathrm{~mm}$ 정도이나 외측으로 갈수록 $45^{\circ}$ 의 상방향으로 향하고 있어 외측에서는 그 거리가 $1 \mathrm{~cm}$ 이 상에 달한다. 따라서 외측 후방으로 갈수록 비강의 내측 으로 절개를 넣어야 한다. ${ }^{5)}$ 비첨의 노출(delivery)을 시 행할 때는 전장에 걸친 절개가 필요하지만 비배의 융비 술(augmentation) 을 하기 위해서는 비익연골 중간각과 내측각 부위의 제한된 절개만으로 충분하다. 비내접근법 으로 비첨에 연골이식을 하는 목적으로도 제한된 경계절 개가 유용하게 사용된다. ${ }^{6)}$ 비중격절개는 관통절개(transfixion incision) 와 반관통절개( hemitransfixion inci- sion) 로 나뉘며 관통절개는 비중격각 부위, 즉 비중격의 미측연을 따라서 절개를 가해 막성비중격을 양쪽으로 관 통시킨다. 이 절개는 연골간절개나 경연골절개와 연결하 여 비내접근법을 이용한 코성형술 때 더 좋은 수술시야 를 얻을 수 있다. 반관통절개는 비중격수술시 많이 사용 되는 방법으로 한 쪽의 점막이나 막성비중격에 절개를 가하고 반대측은 보존한다. 비외접근법을 위해 사용되는 비주횡절개는 역 $\mathrm{V}$ 절개(inverted $\mathrm{V}$ incision) 와 계단상 절개( stair step incision)가 주로 사용되며 비공의 중간 부위나 비주의 가장 좁은 부위에 시행하여 비주 외측에 서 경계절개와 연결한다.

\section{접근법(Approach)}

비성형술을 위한 접근법은 크게 비외접근법과 비내접 근법이 있고 비내접근법은 다시 노출법(delivery approach) 와 비노출법(nondelivery approach)으로 나눌 수 있다. 비외접근법에서는 양측 경계절개와 비주횡절개 를 연결하고 피판을 들어올려 비익연골을 노출시킨다 (Fig. 7). 비외접근법은 여러 가지 장점을 가지고 있다. 우선 술자에게 좋은 시야를 제공하므로 상외측비연골, 비익연골, 비골, 비배부 등을 직시 하에서 수술할 수 있 어 정확한 진단이 가능하며 봉합이나 이식을 보다 정확 한 위치에 시행할 수 있다. 또한 비주로의 접근이 용이하

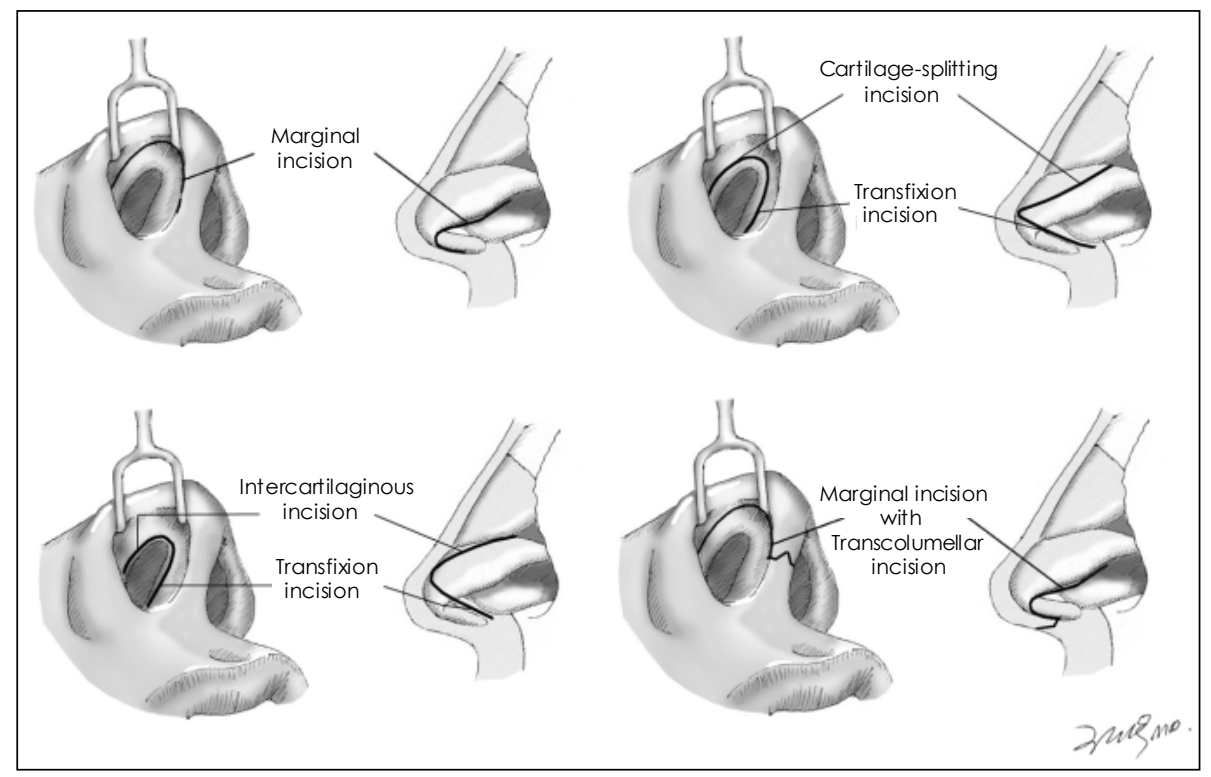

Fig. 6. Incisions used for nasal tip surgery. 


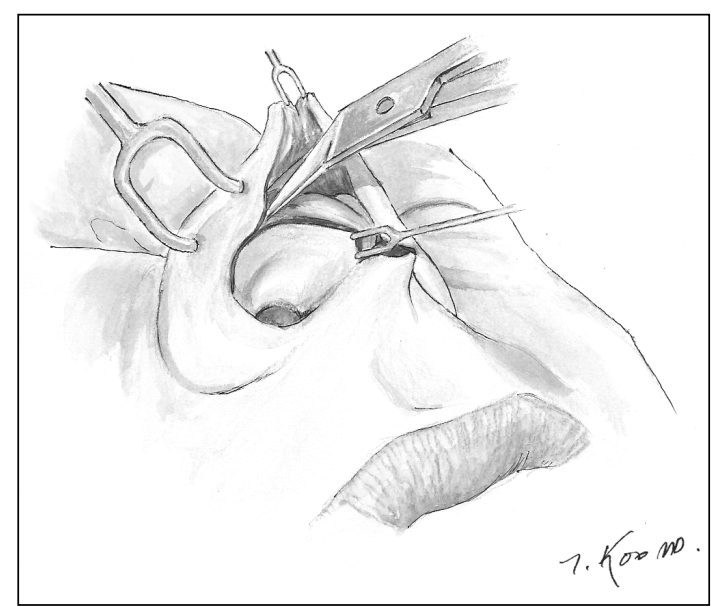

Fig. 7. Open rhinoplasty approach for nasal tip.

고 연골간절개를 사용하지 않아 비밸브 폐색의 위험이 적으며 출혈 부위의 정확한 지혈도 가능하다. 양손을 사 용할 수 있고 교육적 목적으로도 유용하다는 장점도 가 지고 있다. 하지만 비주횡절개에 의한 반흔이 생길 수 있 고 비첨부위의 박리로 부종과 위축의 가능성이 있으며 수술 시간이 길고 수술 중의 변화를 정확히 평가하기 어 렵다는 단점을 가지고 있다. ${ }^{7)}$ 비내접근법 중 노출법은 연골간절개와 경계절개를 가한 후 박리하여 비익연골을 비전정에서 꺼내어( bipedicled chondrocutaneous flap) 조작하는 술식이다. 절개를 내측으로 비주까지 적절히 연장시키고 비첨부위의 박리를 충분히 함으로써 비익연 골을 당김(tension) 없이 노출시킬 수 있다. 노출법은 비첨 성형 시 단순한 비익연골의 부피 감소만으로는 원 하는 모양을 만들 수 없어 남아있는 비익연골의 미측부 분이나 천장부의 조작이 불가피 할 경우 시행할 수 있다. 노출법은 비익연골을 직시 하에서 조작할 수 있어 여러 가지 술식을 사용하기에 용이하다는 장점이 있으나 술 중 박리나 술 후 반흔 형성에 의해 비첨의 변형을 초래 할 수 있으며 비익연골에 비가역적인 손상을 줄 수 있다 는 단점이 있다. 비내접근법 중 비노출법에는 경연골접근 법(transcartilaginous approach)와 역행성접근법(retrograde, eversion approach) 이 있다. 경연골접근법은 비익 연골의 중앙부위, 대게 외측각의 미측연에서 4 6 $\mathrm{mm}$ 정도 떨어진 부위에 단일 절개를 가해 비익연골을 노출시키지 않고 조작하는 방법으로 천장부나 비밸브의
변형 없이 비익연골의 부피 감소나 비첨의 세밀한 조작 (tip refinement) 이 가능하다. 역행성 접근법은 연골간 절개 후 비전정부 피부를 후방에서 앞쪽으로 박리하여 (retrograde undermining) 비익연골 외측각의 두측부 (cephalic half portion) 를 노출시켜 조작할 수 있다.8) 한편, 경계절개를 이용하면 비익연골 중간각 위치에 절 개를 가하여 비익연골의 하부(caudal portion) 를 박리한 후 비첨에 조각된 연골을 위치시키면 어느정도 비첨의 융기와 회전을 도모할 수 있다. ${ }^{6)}$ 이러한 비노출법은 간 단하고 반흔조직이 적어 술후 변형이 거의 없지만 시야 가 좋지 않아 대칭성을 유지하며 정확히 조작하기 어려 운 단점이 있어 가벼운 정도의 변형이 있는 비첨에 선 택적으로 사용된다.

\section{비첨 개조 술식(Tip modification techniques)}

비첨의 개조(modification) 를 위한 구체적인 조작에는 절제(excision)나 절개(incision) 를 통한 비익연골조각 법(cartilage sculpturing), 봉합법(suture technique), 그리고 연골이식법(cartilage graft) 등이 있다.9)

비익연골조각법(C artilage sculpturing)

비첨 성형이 필요한 환자는 비익연골 외측각이 너무 볼록하여(convex) 둥근 모양의 비첨을 가지며 상하 길 이가 길어 비첨의 하방 회전을 동반하고 있는 경우가 많 다. 비첨성형시 비익연골의 부피 감소가 요구되는 경우 로는 심한 비첨융기(excess tip projection), 너무 볼록 한 비익연골( excess convexity of alar), 그리고 비첨의 삼각형 모양 윤곽의 소실(lack of triangular definition to the tip) 등이 있으며 특히 비첨부 피부와 비익연골의 비후가 동반된 경우가 많다. 비익연골의 절제를 이용한 술식에는 연속띠법(complete strip, cephalic trim, cephalic resection) 과 단속띠법( incomplete strip, interrupted strip) 이 있다. ${ }^{10)}$ 연속띠법은 비익연골 외측각의 두 측부(cephalic portion) 를 절제하는데 남아있는 띠(strip) 의 연속성을 유지하여 비익연골 폭의 4 8 $\mathrm{mm}$, 혹은 원 비익연골 부피의 $75 \%$ 를 보존하는 술식으로 남게되는 띠의 폭은 비익연골의 강직성에 반비례하게 된다. 비익 연골을 너무 많이 절제하면 지지구조가 손상되어 비첨 모양의 변화나 비페색 등을 초래할 수 있다. 이러한 연속 
띠법에 추가하여 중간각 부위에 칼자국을 내거나 (alternating incomplete incisions) 연골간 봉합(transdormal suture narrowing), 혹은 압착(gentle morselization) 을 시행하여 좀 더 많은 상방향회전을 얻을 수 있다. 단 속띠법은 비익연골의 미측부위(caudal margin) 를 절제 하여 일부를 제거하고 다시 연결하는 방법으로 비익연골 을 많이 절제할수록, 내측보다는 외측에서 절제할수록 더 많은 상방향회전을 얻을 수 있다. ${ }^{11)}$ 단속띠법은 연속 띠법보다 많은 비첨의 상방향회전을 얻을 수 있으나 약 간의 비첨융기의 소실을 동반하며 치유 후 비첨의 모습 을 정확히 예측하기 힘든 단점이 있다.

\section{봉합법(Suture technique)}

비첨 부위의 피부가 얇은 경우 과도한 연골의 절제나 비익연골의 절개 후 봉합(dome division), 혹은 비첨이 식(tip graft) 후에 변형을 초래할 수 있다. 봉합법은 비 첨의 폭을 좁히거나 비첨 융기를 증가시킬 때 효과적으 로 사용할 수 있는 술식으로 특히 비익연골이 단단하고 주먹코(bulbous tip) 인 경우 효과적이다. 비익연골 외측 각을 연골간봉합(transdomal suture) 으로 모아주면 비 첨 융기와 상방향회전을 증가시킬 수 있으며 필요한 경 우 양측 비익연골 천장부(dome) 에 각각 별개의 봉합을 시행하여 서로 다른 변화를 줄 수 도 있다. 봉합법은 기 대하던 효과가 얻어지지 않았을 때 봉합을 제거할 수 있 어 가역적이고, 봉합법으로 적절하지 않다고 판단되면 비익연골의 절개 후 봉합(dome division) 과 같은 좀 더 적극적인 술식을 사용할 수 있다. 또한 비익연골 절제 후 시간이 지나면서 가장자리가 예리한 사각형태로 되는 것 을 피할 수 있으며 비첨의 곡선 형태를 유지할 수 있는 장점이 있다. 봉합재료로는 비흡수사인 5- 0 prolene이 나 흡수사로 봉합의 염증반응이나 탈출을 최소화하는 5- O PDS 등이 사용된다. 연골간봉합(transdomal suture) 은 비첨의 폭을 줄이고 세밀히 하는(refinement) 효 과가 있으며 특히 넓은 비익연골(wide alar cartilages), 얇은 비첨부 피부(thin skin), 연약한 비익 측벽(delicate alar sidewalls) 의 3 가지 특징을 갖고 있는 trapezoid nose의 경우 좋은 적응증이 된다. ${ }^{12)}$ 이는 천장부간의 거 리(interdomal distance) 를 줄이며 더불어 비첨의 윤곽과 구조적인 지지를 증가시킬 수 있는 장점이 있다(Fig. 8).

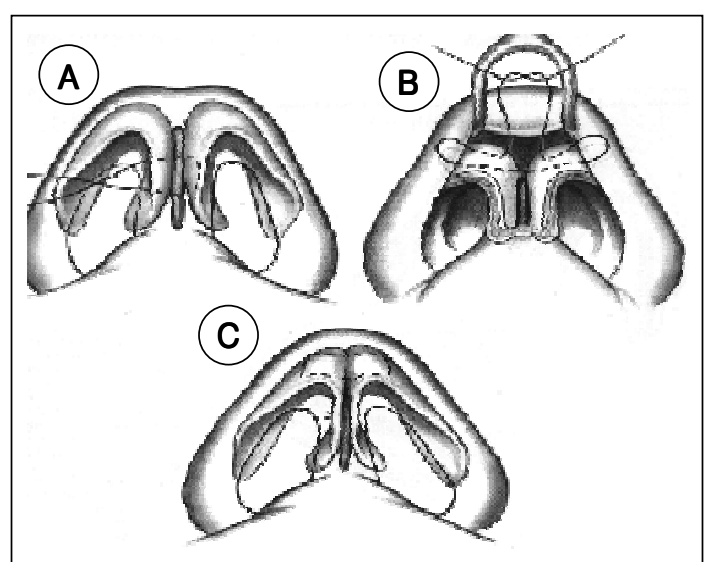

Fig. 8. A : Columellar suture, B \& C : Transdomal and interdomal suture.

Table 2. Indications and contraindications of suture technique

Indications

Narrowing of the bulbous nasal tip with an obtuse domal angle

Decrease in the interdomal angle (bifid tip) Increase in tip projection Increase in tip rotation

Relative contraindications Weak pliable cartilages Narrow tip cartilages Marked tip asymmetry Excessively rotated nasal tip Over projected nasal tip

봉합법은 뭉툭한 천장부를 가진 주먹코, 이분된 비첨 (bifid tip) 의 경우 효과적 이며, 비첨의 융기와 회전을 위해서도 사용된다. 하지만 심한 비첨의 비대칭이나 과 도하게 회전된 비첨, 좁고 쉽게 휘어지는 비익연골의 경 우 피하는 것이 바람직하다 ( T able 2).

\section{연골이식법(C artilage graft)}

적절한 비첨의 윤곽을 얻기 위해 가장 널리 사용되는 방법 중 하나로 재수술의 경우에도 결과가 우수하다. 재 료로는 연골을 조각하거나 분쇄하여 사용한다. 연골이식 의 문제점으로는 이식물의 탈출(graft displacement), 이식물의 가시화(visibility), 이식물의 편평해짐(flattening) 등이 있을 수 있다. 비주 버팀목(columellar strut) 
은 비첨융기의 기본 술식으로 자가 연골( 주로 비중격연 골)을 이용하여 버팀목(strut)을 만들어 비익연골의 중 간각과 내측각의 사이에 위치시킨다Fig. 9). 이로써 비 첨의 지지효과와 적당한 비첨융기, 그리고 비공모양의 변화를 얻을 수 있다. 버팀목은 비극( nasal spine)에 직 접 닿지 않아도 비첨융기 효과를 나타내며 특히 방패이 식이나 모자이식을 할 경우 지지구조로써 사용된다. 모 자이식(cap graft, on- lay graft, supradomal graft)는 비첨 한정점을 잘 나타낼 수 있게 $6 \sim 8 \mathrm{~mm}$ 정도의 폭 으로 연골을 한 겹 또는 여러 겹으로 겹쳐서 사용한다

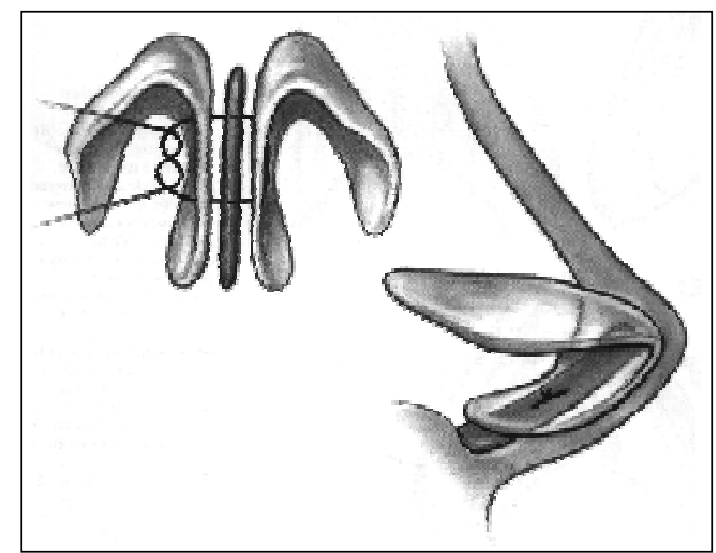

Fig. 9. Columellar strut.

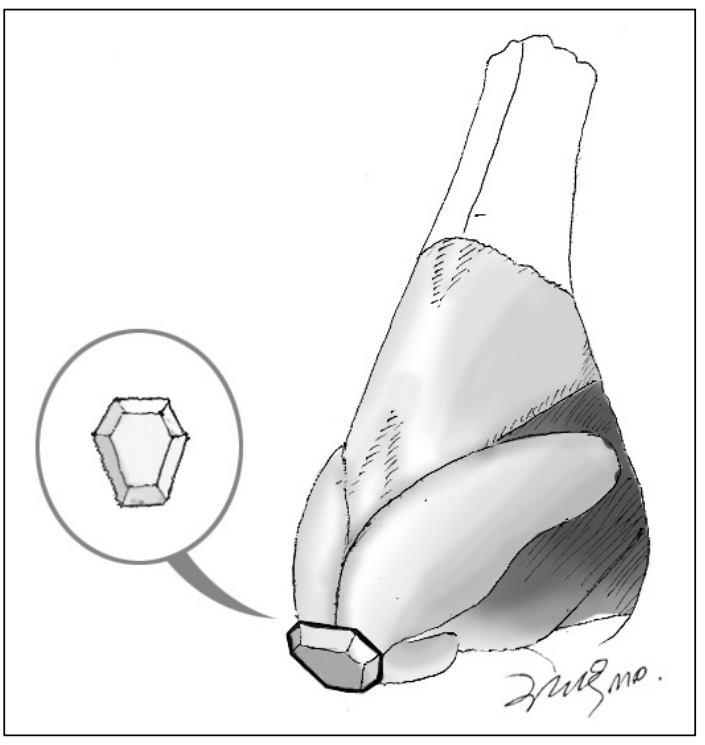

Fig. 10. Tip onlay graft on the domal area.
(Fig. 10). 여러 겹으로 올릴 경우 비주 버팀목과 함께 시 행하는 것이 좋으며 비첨의 윤곽과 융기를 향상시킬 수 있다. 방패이식( shield graft)은 주로 비중격연골을 이용 하며 은행잎 모양으로 조각하여 양쪽 끝이 비첨 한정점 을 나타낼 수 있도록 상부는 $6 \sim 8 \mathrm{~mm}$ 의 폭을 갖도록 한 다. ${ }^{13)}$ 이 방패이식은 비첨의 소엽하부(infralobular segment) 길이를 연장시켜 비첨융기를 증가시킨다 Fig. 11). 길이가 길면 비첨융기는 물론 코전체의 길이를 늘리는 효과를 기대할 수 있으며, 길이가 짧은 경우 비첨융기와 함께 뒤로 젖혀질 가능성이 있으므로 비첨의 상방향회 전이 커질 수 있다(Fig. 12).

\section{비첨의 회전(Tip rotation)}

비첨의 회전은 기본적으로 비익연골에 대한 외과적 조 작으로 얻어지나 비익연골과 인접한 여러 구조에 대한 추가적인 술기로 회전 정도를 증가시킬 수 있다. 치유 과

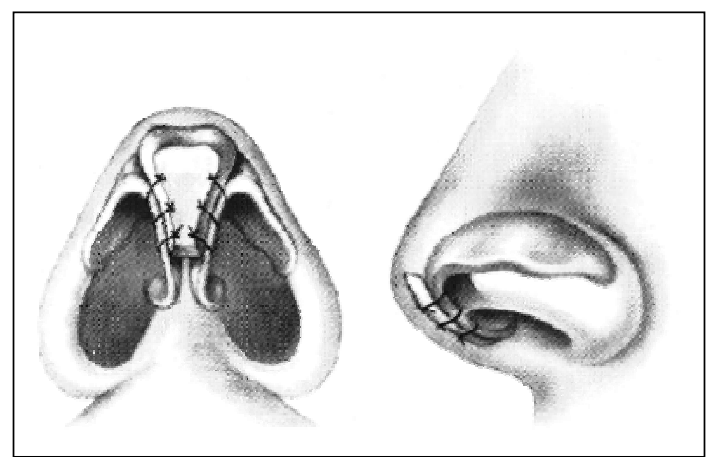

Fig. 11. Shield graft.

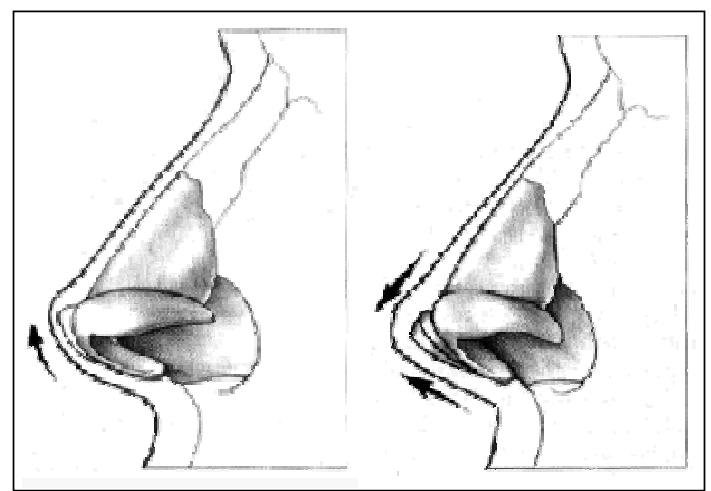

Fig. 12. Different effect of shield graft according to the different shapes of shield graft. 
정(healing dynamics)이 비첨 회전에 가장 중요한 역할 을 담당하며 일부 비첨 회전을 위한 조작으로는 적절한 비첨 융기 효과도 추가적으로 얻을 수 있다. 대게 비첨의 회전이라고 하면 상방향회전을 의미하며 연속띠법, 혹은 단속띠법을 이용한 비익연골 외측각의 절제, 비배부연골 이나 비중격의 절제, 봉합법이나 비첨 이식법 등의 다양 한 술식을 사용할 수 있다(T able 3).

\section{비첨융기(Tip projection)}

비첨의 융기는 전상악부(premaxillary component), 비주부(columellar component), 소엽하부(infralobular component) 의 3 가지 요소로 결정된다.

Table 3. Graded techniques for increasing tip rotation

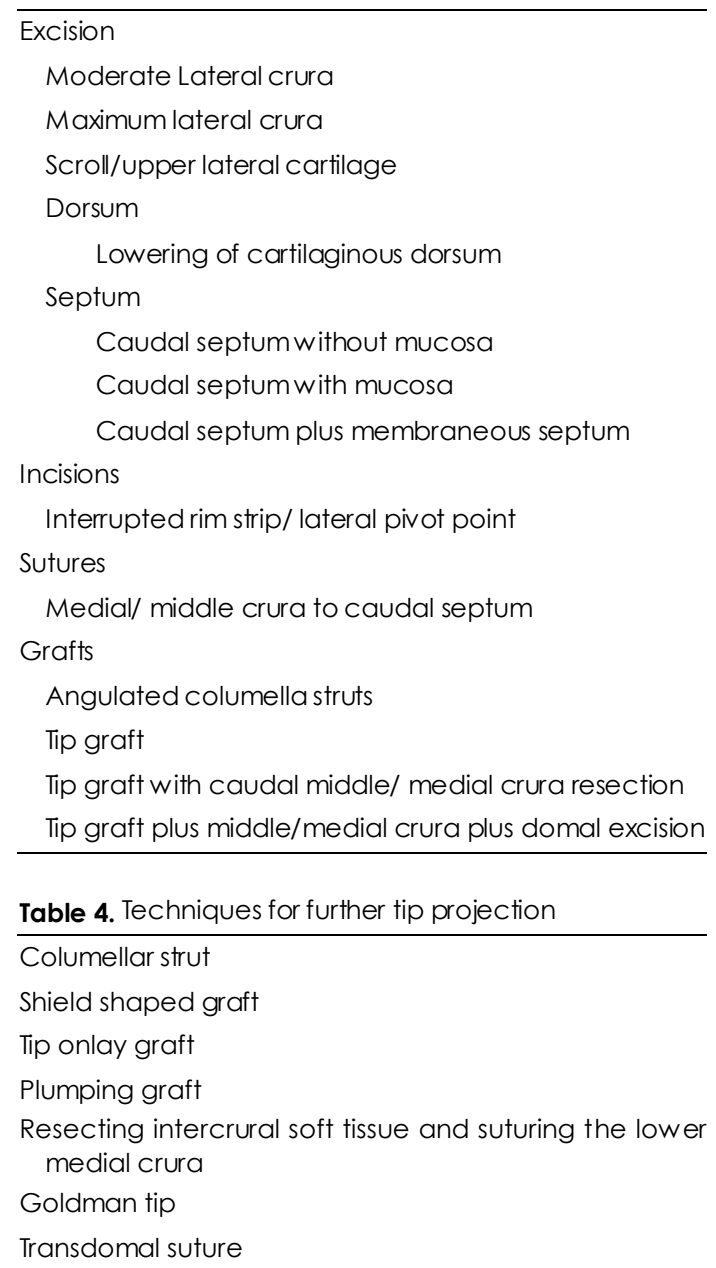

비익연골의 해부학적 특성상 기존의 비첨의 지지 구조 및 융기를 보존하는 것이 중요하며 특히 천장부(domal area) 에서는 절개( incision), 절제(excision) 및 박리(dissection) 를 제한적으로 사용해야 하며 complete rim strip을 보존해야 한다. 비첨을 높이기 위해서 비주 버팀 목, 방패이식, 모자이식, 받침이식, 연골간 봉합 등을 사 용할 수 있으며 내측각 사이의 연조직을 제거 후 내측각 을 봉합하는 방법도 있다 (T able 4). 한편, 서양인에서처 럼 비첨이나 비배부가 필요이상으로 높아 비첨의 저하가 요구되는 경우에는 내측 및 외측각 절제 후 봉합이나 미 측 비중격 절제, 관통절개법 등을 이용할 수 있다.

\section{기타 비첨의 교정}

비첨 폭의 이상은 편평코(boxy nose) 와 주먹코(bulbous nose) 로 나눌 수 있다. 비익연골 중간각의 정상 분 산각도는 $60^{\circ}$ 정도로 이보다 각이 커서 비첨이 평평해 보일 때 편평코라고 하며 각이 작아서 비첨이 동그랗게 보여 비첨 한정점이 잘 나타나지 않을 때 주먹코라고 한 다(Fig. 13). 편평코의 경우 기저면에서(basilar view) 관찰했을 때 이상적인 삼각형의 형태가 아닌 사각형 모 양(square) 을 갖게 된다. 분산각이 정상보다 커져있고 외 측각과 비익연에 절흔이 생기며(notched) 비익저(alar base) 가 많이 얇아져 있다. 치료는 두 가지 경우로 나누 어 생각할 수 있는데, 비첨부의 피부가 얇고 비첨의 융기 는 적절한 경우에는 비익연골 중간각의 두측부위를 절제 하고(cephalic resection), 중간에 위치한(intervening)

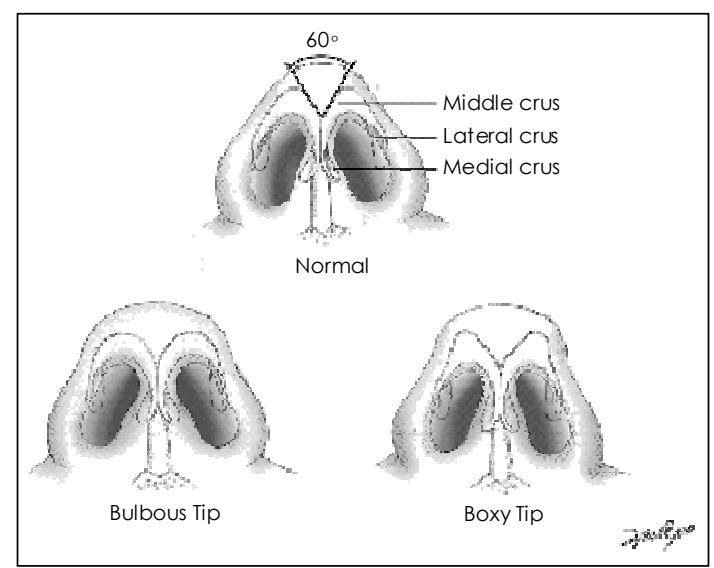

Fig. 13. Alar cartilage shape in bulbous and boxy tip. 


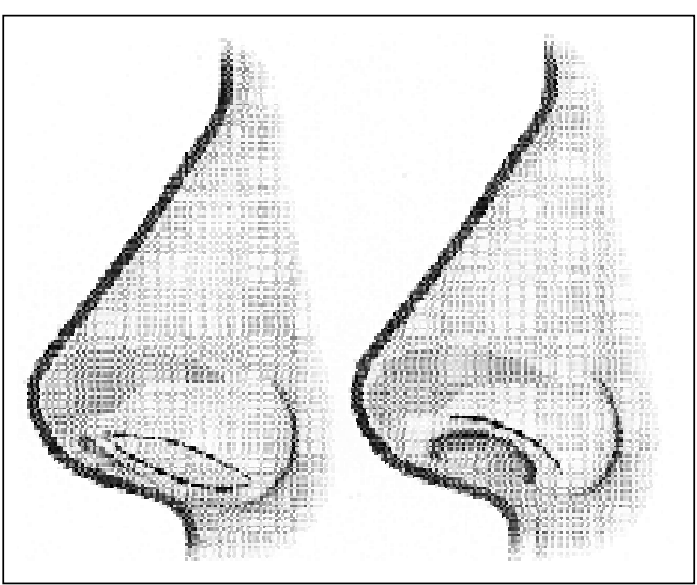

Fig. 14. Surgery for hanging alar : Vestibular skin is removed and sutured.

연조직을 제거한 후, 연골간 봉합을 시행한다. 한편, 비 첨부의 피부가 두껍고 비첨의 융기가 부족한 경우에는 비주 버팀목, 외측각 절제, 연골간 봉합, 비첨 이식 등을 사용할 수 있다. 주먹코는 비익연골이 지나치게 크고 폭 이 넓으므로 비익연골의 상부절제를 통해 교정한다. ${ }^{14)}$ 한편 비첨하소엽부(infratip lobule region)의 위치 차이 (positional difference)나 미측 비중격(caudal septum) 의 치우침(deflection)에 의해 비첨의 비대칭(asy $\mathrm{mm}$ etric tip) 이 발생할 수 있으며 후자의 경우 비중격의 변 형을 교정함으로써 비대칭이 소실될 수 있다. 비첨이 경 도 및 중등도의 비대칭일 경우 좌우 비익연골을 일치시 키려는(match) 시도가 일차적이며 심한 비대칭일 경우 새로운 비첨의 모양(configuration) 을 만들어야 한다. 외 비 전체가 비대칭일 경우 비배부(dorsum) 의 교정을 첫 번째로 시행한다. Bifid tip은 비익연골이 너무 볼록(convex)하여 서로 멀어지게 되는 경우로 연조직이 얇아 비 첨이 두 개로 갈라져 보인다( bifidity). 치료로는 비익연골 의 잉여 부분을 절제하고 필요하면 중간각의 상연(cephalic border)과 연조직까지 제거할 수 있다. 양측의 중 간각을 근접시키기 위해 봉합을 시행하고 분쇄된(crushed) 연골로 결손된 연조직을 보충한다. 비익의 일부가 수축(retracted) 되어 깊게 패인(notched) 경우 이개연 골과 피부의 복합이식(composite graft)을 이용하여 교 정할 수 있다. 비익연골의 하연을 따라서 절개선을 넣고 그 사이에 이식물을 삽입한 후 연골은 연골끼리, 피부는
피부끼리 봉합한다. 한편 비익이 늘어진(hanging) 경우 비전정 피부에 절개를 가해 일부 제거한 후 봉합하여 교 정할 수 있다(Fig. 14).

\section{비첨성형술의 합병증}

비익의 수축(alar retraction) 이 나타날 수 있다. 이는 주로 비익연골 외측각이나 비전정점막(vestibular mu$\operatorname{cosa}$ )의 과도한 절제 후 발생하며 경계절개의 부적절한 봉합에 의해서도 나타날 수 있다. 술 후 비첨의 비대칭도 흔히 나타나는 합병증이다. 여러 원인이 있지만 주로 천 장부의 봉합이 대칭적으로 이루어지지 않았을 때 발생한 다. Bossae는 비첨의 천장부가 혹처럼 돌출되는 것으로 외측각의 과도 절제나 연골분리술식(cartilage- splitting technique)에 의한 외측각의 약화가 원인이 된다. 비첨 의 피부가 얇고 연골이 두꺼우며 비첨이 이분되어 있는 (bifid) 환자의 경우 Bossae의 발생 위험이 높다. ${ }^{15)}$ 그 외에 경비주절개로 인한 비주의 반흔이나 내/외 비밸브 변형에 의한 비폐색 등이 비첨성형술 후 생길 수 있는 합병증이다.

\section{결 론}

비첨성형술은 코성형술의 마무리 단계로 코성형술의 성공을 좌우하는 핵심적인 과정이다. 따라서 비첨을 이 루고 있는 비익연골의 해부학적 특징과 비첨을 지지하고 있는 구조 및 상호간의 역학관계를 충분히 이해하는 것 이 중요하다. 또한 수술 전 비첨 형태에 대한 세밀한 분 석이 필수적이며 각 술식에 의해 예측되는 결과를 인지 하고 있어야 하겠다.

중심 단어 : 코성형술· 비첨성형술.

\section{REFERENCES}

1) Johnson CM, Toriumi DM. Open structure rhinoplasty. Philadelphia; WB Sanders;1990. p.23-9.

2) Tardy JR ME. Rhinoplasty: the art and the science. Philadelphia; WB Sanders;1997. p.23-7.

3) Anderson JR. A reasoned approach to the nasal base. Arch Otolaryngol 1984;110:349-58.

4) Daniel RK. Rhinoplasty. Newport beach; Little Brown Co; 1992. p.677-704.

5) Johnson CM, Toriumi DM. Open structure rhinoplasty. 
Philadelphia; WB Sanders;1990. p.61-71.

6) 장용주. Rhinoplasty: endonasal approach 제 6 회 서울아산 병원 · 삼성서울병원 Otolaryngology-Update;2004. p.163-4. 7) Adamson PA. Open rhinoplasty. Otolaryngol Clin North Am 1987;20:837-52.

8) Romo T, Millman AL. Aesthetic facial plastic surgery. New York-Stuttgart; Thieme;2000. p.71-87.

9) Gunter JP, Rohrich RJ. Management of the deviated nose. The importance of septal reconstruction. Clin Plast Surg 1988;15:43-55.

10) Rich JS, Friedman WH, Pearlman SJ. The effects of lower lateral cartilage excision on nasaltip projection. Arch Otolaryngol Head Neck Surg 1991;117:56-9.

11) Tardy JR ME. Rhinoplasty. In:Cummings $C W$, Fredrickson $J M$, Harker LA, Krause CJ, Richardson MA, Schuller DE, editors. Otolaryngology Head and Neck Surgery. 3rd ed. St. Lousi; Mosby Year Book;1998. p.964-87.

12) Tardy JR ME, Toriumi DM, Hecht DA. Philosophy and principles of rhinoplasty. In: Papel ID, Frodel J, Larrabee WF, Nachlas N, Park SS, Sykes JM, Toriumi DM, editors. Facial Plastic and Reconstructive Surgery. 2nd ed. New YorkStuttgart; Thieme;2002. p.369-89.

13) Kamer FM, Churukian MM. Shield graft for the nasal tip. Arch Otolaryngol 1984;110:608-10.

14) Rohrich RJ, Adams WP. The boxy nasal tip: classification and management based on alar cartilage suturing techniques. Plast Reconstr Surg 2001;107:1849-63.

15) Behrbohm H, Tardy ME. Essentials of septorhinoplasty. New York-Stuttgart; Thieme;2004. p.137-48. 